\title{
Methods for Non-Destructively Separating or Reannealing the Strands of Circular Duplex DNA Chromosomes
}

\author{
Ken Biegeleisen \\ Physician in Private Practice, New York, NY, USA \\ Email: kb@notahelix.net
}

How to cite this paper: Biegeleisen, K. (2017) Methods for Non-Destructively Separating or Reannealing the Strands of Circular Duplex DNA Chromosomes. Open Access Library Journal, 4: e3353.

https://doi.org/10.4236/oalib.1103353

Received: January 4, 2017

Accepted: February 5, 2017

Published: February 9, 2017

Copyright $\odot 2017$ by author and Open Access Library Inc.

This work is licensed under the Creative Commons Attribution International License (CC BY 4.0).

http://creativecommons.org/licenses/by/4.0/

\section{(c) (†) Open Access}

\begin{abstract}
Although it is not widely-known, the strands of circular duplex plasmid and viral chromosomes have been non-destructively separated, and the separated strands have been reconstituted to yield a new duplex structure with all the properties of the native chromosome restored. This suggests a paranemic structure for the DNA, that is, a structure whose strands are not topologically linked by plectonemic (i.e., Watson-Crick) twists. The reason that these phenomena are largely unknown to the general scientific public is that they were either published in obscure journals, or not published at all. Moreover, the methods employed to obtain these results were very difficult, time-consuming and expensive, wherefore they are not likely to be repeated anytime soon. Since these phenomena would be of great interest to the general scientific public, the experiments therefore need to be repeated, but in a way that is easy, fast and inexpensive to perform, so that the results may be readily reproduced in other laboratories. Two such experiments are described herein.
\end{abstract}

\section{Subject Areas}

Biochemistry, Genomics, Molecular Biology

\section{Keywords}

DNA, Z DNA, Helix, Circular, Denature, Plectonemic, Paranemic, Side-by-Side

\section{Introduction}

This manuscript teaches a method which will likely result in the non-destructive separation of the strands of a native circular duplex chromosome, which would be impossible if the strands of the DNA had the plectonemic, i.e., topologicallyintertwined Watson-Crick double-helix structure. 
The word "likely", in the above sentence, may evoke a state of serious cognitive dissonance, but such a non-destructive separation has already been reported by Tai Te $\mathrm{Wu}$ [1]. That report, however, involved a complex and difficult experimental protocol, and was published in a relatively obscure journal. Although, to the best of my knowledge, the $\mathrm{Wu}$ publication has never been disputed in any way, it has nevertheless been cavalierly ignored for 20 years. Moreover, since the study was costly, and required many months of hard labor, it is very unlikely that anyone will ever attempt to repeat it.

And yet the experiment needs to be repeated. We therefore need a new protocol which is simple, inexpensive, and readily-reproduced in any lab where plasmid DNA research is done. I have deduced such a protocol. I shall first present it, then explain the history and rationale behind it.

Then I shall present a second, "sister" protocol, which will result in the reannealing of the separated strands of the plasmid back to the native duplex structure, with all its physical and topological properties restored. This also would be impossible if the DNA had the plectonemic Watson-Crick double-helix structure. And yet this too has already been accomplished, but never published, for reasons to be explained herein.

\section{Materials and Methods}

\subsection{Strand Separation Protocol}

What follows is a concise description of the experiment which will likely bring about the non-destructive separation of plasmid single strands. A detailed protocol will be posted at https://NotAHelix.net, upon publication of this manuscript.

The protocol has 7 steps. Aside from the dialysis step, and the verification of the single-stranded product by electron microscopy, the remainder of the work can be done in a matter of minutes, at almost no expense, in almost any lab which employs small circular DNA in their research.

The protocol begins with 4 simple stock solutions:

$10 \underline{\mathrm{mM}}$ Tris $\cdot \mathrm{HCl}(\mathrm{pH}$ 8), $0.5 \underline{\mathrm{mM}}$ EDTA

$1 \underline{\mathrm{M} \mathrm{NaCl}}$

\section{$1.1 \underline{\mathrm{M}} \mathrm{NaOH}$}

\section{$1.1 \underline{\mathrm{M}}$ Tris $\cdot \mathrm{HCl}$}

The recommended DNA for this experiment is pBR322, available from Life Technologies, or from New England Biolabs. The logic behind using this DNA is that it is essential for the "sister" reannealing experiment, to be presented below. The "sister" experiment requires use of "nicking" enzymes (i.e., site-specific, strand specific nucleases) that have cleavage sites in pBR322, wherefore it is desirable that pBR322 be used for both experiments.

The simple procedure is as follows:

1) The pBR322 DNA, which is sold at a high concentration $(500 \mu \mathrm{g} / \mathrm{ml})$, is first diluted to $50 \mu \mathrm{g} / \mathrm{ml}$ by addition of 9 volumes of $10 \underline{\mathrm{mM}}$ Tris. $\mathrm{HCl}, \mathrm{pH} 8,0.5$ mM EDTA. 
2) One-half volume of $1 \underline{\mathrm{M} \mathrm{NaCl}}$ is added, giving a final salt concentration of $0.33 \mathrm{M}$. (This relatively high salt concentration may be necessary to bring about the irreversible alkali denaturation in the next step).

3) One-tenth volume of $1.1 \underline{\mathrm{M} \mathrm{NaOH}}$, is added. (This amount of base is precisely-calculated to raise the $\mathrm{pH}$ to at least 13 , the $\mathrm{pH}$ at which circular DNA is irreversibly denatured to a form known as "Form IV").

4) The added $\mathrm{NaOH}$ is neutralized by addition of an exactly equal volume of 1.1 $\underline{\mathrm{M}}$ Tris. $\mathrm{HCl}$. This will reduce the $\mathrm{pH}$ to about 8 . (This is only done to reduce the possibility of hydrolysis of the DNA sugar-phosphate backbone by prolonged exposure to high $\mathrm{pH}$ ).

5) The Form IV, now in a high-salt environment, is dialyzed in the cold against the first buffer (10 $\mathrm{mM}$ Tris. $\mathrm{HCl}, \mathrm{pH} 8,0.5 \mathrm{mM}$ EDTA). (This is necessary because the formamide-based protocol for separating the strands of Form IV, described in the next step, has only been reported in a low-salt setting).

6) The Form IV is removed from dialysis, one volume is mixed with 9 volumes of formamide, and the mixture is incubated at $80^{\circ}$ for 10 minutes. (This should non-destructively separate the strands of the Form IV, resulting in a nearly-pure population of single-stranded circular DNA).

7) The DNA can now be used directly, without further processing, as a hyperphase for electron microscopy, which will identify the product as intact, single-stranded circular DNA.

\subsection{Basic Design of the Experiment}

In 1996, Tai Te Wu separated the intact strands of two different plasmids by ordinary agarose gel electrophoresis, thus proving that the strands of those plasmids are not topologically intertwined, i.e., that they do not have the Watson-Crick plectonemic structure [1]. The key to the separation was the isolation of the DNA during the "stationary phase" of cell growth, where the cell sheet is confluent and DNA synthesis essentially ceases. Transcription, however, is ongoing. Bound m-RNA creates large numbers of D-loops in the "sense" strand, i.e., the transcribed strand of the plasmid, but very few such D-loops will be found in the "antisense" strand. The two strands, under those circumstances, therefore no longer have the same structure. When subjected to low-voltage agarose gel electrophoresis, the sense and antisense strands gradually separated into two bands, over a 12 - 36 hour period.

The experiment was rigorously and multiplicatively-controlled, with respect to persuasively establishing the identities of the two bands, and, moreover, with respect to ruling out accidental strand cleavage as an explanation for the strand separation. In fact, when the control DNA strands were intentionally cleaved, they did not separate, demonstrating that not only were the experimental DNA strands intact throughout, but that intact strands were absolutely required to effect strand separation.

To date, the $\mathrm{Wu}$ experiment has been the only successful one-step procedure for the separation of the strands of a duplex circular plasmid. In the earlier days 
of small-DNA research, in the 1960s, all attempts to separate the strands of circular plasmids, by use of the then-common modes of denaturation, had been unsuccessful (Table 1). This led logically, but perhaps prematurely, to the conclusion that the strands of circular plasmid DNA were always topologically-intertwined, and could not be separated unless one or both were cleaved.

As indicated in the table, denaturation of circular DNA was possible, but it required strong denaturants, and even then it was not accompanied by strand separation. The term "denaturation", in that setting, meant irreversible disruption of base-pairing (as verified by changes in $\mathrm{A}_{260}$ ), in a setting in which the two strands of the plasmid remained unequivocally linked. The resulting duplex non-base-paired structure was referred to by various names, of which I shall adhere to the Roman numeral system introduced by Vinograd [2] and extended by Strider and Warner [4] [5]:

Form I: Intact native duplex circular DNA, which is always superhelical.

Form II: Nicked Form I, which is relaxed, i.e., lacking superhelicity.

Form III: Form I after full-duplex-cleavage, i.e., linear duplex DNA.

Form IV: Alkali-denatured Form I.

We shall thus refer to alkali-denatured circular DNA as Form IV. The singular characteristics of Form IV are that:

1) it is astonishingly compact, sedimenting in velocity ultracentrifugation experiments at $200 \%-300 \%$ the rate of native DNA, and

2) unlike linear DNA, it is remarkably resistant to renaturation.

Renaturation of Form IV is possible but difficult, requiring pinpoint control of $\mathrm{pH}$, temperature and ionic strength [4] [5] [6].

Dozens of papers on Form IV were published between 1963 [2] and 1981 [6], after which the molecular biological community lost all interest in it. Conspicuously absent from all those papers was any proposal for a Form IV structure, or any explanation for its extraordinary compactness. This gap in our knowledge may have been closed by the recent publication of a detailed molecular model for Form IV, which accounts for all of its properties, including its high sedimentation coefficient $(S)$ in velocity ultracentrifugation studies [7] [8].

Table 1. History of early attempts to denature circular DNA.

\begin{tabular}{|c|c|c|}
\hline Denaturant & Result with linear DNA & Result with circular DNA \\
\hline Boiling & Strand separation & Nothing - no strand separation ${ }^{1}$ \\
\hline Alkali & Strand separation & Denaturation to Form $\mathrm{IV}^{2}$ \\
\hline Weak organic solvents ${ }^{3}$ & Strand separation & Nothing - no strand separation \\
\hline Strong organic solvents ${ }^{4}$ & Strand separation & Denaturation to Form IV ${ }^{2}$ \\
\hline
\end{tabular}

${ }^{1}$ As long as the two strands of a circular chromosome are intact, boiling has no effect [2]. If one or both strands are nicked, however, the strands will then usually behave like the strands of linear DNA, and separate when boiled; ${ }^{2}$ Form IV, described below, is a tremendously-compact duplex form of DNA which appears to be stabilized by salt bridges between phosphate groups. It appears at $\mathrm{pH} \mathrm{13}$, and does not change with further increases in $\mathrm{pH}$. Although unequivocally duplex, it is also unequivocally denatured, that is, demonstrably devoid of base-pairing. It is, moreover, extremely resistant to renaturation, which, although possible, requires pinpoint-control of $\mathrm{pH}$, temperature and ionic strength; ${ }^{3}$ For example, formamide [3]; ${ }^{4}$ For example, formaldehyde [2] [3]. 
None of the early researchers had any incentive to attempt the further separation of the strands of Form IV, because they all believed that such separation was topologically impossible. The current Form IV model, however, suggests that strand separation may be possible.

It is my firm belief that not only is the non-destructive separation of the strands of Form IV possible, but that this has already been accomplished and reported long ago, by Stettler et al (1979) [9], employing simple formamide denaturation. These authors, however, did not realize what they had done, because they believed themselves to have been dealing with a novel, hitherto unknown DNA form, which they referred to as "Form V". In other words, what they reported was the easy separation of the strands of "Form V", by formamide denaturation.

It is my belief that "Form V" is really Form IV. If so, then the repetition of the $\mathrm{Wu}$ separation of intact plasmid strands, which, in its day, was difficult, time-consuming and expensive [1], can now be accomplished in two simple steps:

1) alkali-denaturation of Form I to Form IV, and

2) formamide denaturation of Form IV to single strands.

Why two steps? Because neither denaturant alone can accomplish the separation. Form IV, once it appears at $\mathrm{pH} 13$, is stable under nearly all conditions of $\mathrm{pH}$, temperature and ionic strength [4] [5] [6]. In particular, it cannot be altered by increasing the $\mathrm{pH}$ beyond 13 (reference [10]). But, as just noted above, it appears that it can be further denatured by formamide. Why not then use formamide directly on Form I? Because it was shown, in the early days of DNA denaturation research, that Form I cannot be irreversibly-denatured (i.e., converted to Form IV) by formamide [3]. Therefore, both alkali and formamide denaturation will be required to separate the plasmid strands.

Thus, if the theory underlying the above-described experiment is valid, we can accomplish today, in two extremely simple, rapid and inexpensive steps, that which took Tai Te Wu months of hard and expensive labor to accomplish in 1996 [1].

\subsection{Rationale for the Experimental Protocol}

The two-step strand-separation protocol outlined above, although almost ridiculously simple on its face, was actually the outcome of 44 years of inquiry into the topology of circular DNA. A complete discussion of circular DNA topology has been published elsewhere [8] [11] [12] [13] [14] [15], as a series of lengthy PowerPoint presentations. To condense them all to a few manuscript pages is obviously impossible, but perhaps by focusing on the most relevant aspects, the logic which underlies the protocol will become sufficiently clear.

The first step in the non-destructive separation of plasmid single strands, alkali denaturation of Form I to Form IV, has been well-known for over 50 years. But Form IV is still double-stranded. The key step in strand separation is the second step, i.e., formamide denaturation of Form IV to single strands, which is 
totally unknown. And yet it has almost surely been accomplished in the past.

The theory I shall now present is that Charles Weissmann, the senior author of Stettler et al (1979) [9], inadvertently created Form IV, and non-destructively separated its strands by denaturation in $90 \%$ formamide. The correctness of this view rests upon two difficult but defensible propositions: (1) That the data of Charles Weissmann can be trusted, even though his conclusions were questionable, and (2) that his ostensibly-novel "Form V" was really Form IV, created under circumstances which inadvertently caused its true nature to be concealed from its creators.

Concerning the first difficult proposition, Charles Weissmann, the recipient of numerous international awards and honors, was the co-founder of the biotech giant, Biogen. While there are some who might question the reliability of any biotech company which must, first and foremost, answer to the demands of a mercantile board of directors, the fact of the matter is that we all live in a world in which that has become the norm, and we must therefore deal with that world as it is. More to the point, we may note that Weissmann has been in the public eye throughout his entire career, and, while I profoundly disagree with many of his logical deductions and conclusions, I have never had any reason to doubt the veracity of any of his published data.

With respect to the second difficult proposition, that "Form V" is really Form IV, I have gone to great lengths to study and analyze Stettler et al in extreme detail (of which only a concise overview can be presented here; the fully-detailed analyses have been published elsewhere [16] [17]). My conclusions are therefore not presented lightly, but represent the product of many years of consideration and deliberation.

The Weissmann study (Stettler et al [9]) was done in response to a direct public suggestion by Francis Crick himself. The story begins in 1976, when the New Zealand chemist Gordon Rodley and his associates published a paranemic, or topologically-non-helical structure for DNA [18]. They called their structure the "side-by-side" structure. It is a theoretical structure, totally based upon the ordinary Watson-Crick plectonemic structure, except that the direction of secondary helical winding reverses every 5 base pairs. That gives rise to an undulating ribbon-like structure whose strands never fully cross, and are therefore not topologically-intertwined [19] (Figure 1). With only slight backbone modifications, such a structure could be closed into a circle with a linking number $\left(\mathrm{L}_{\mathrm{K}}\right)$ of zero, which, upon denaturation, would - in theory at least - break apart into intact single strands.

The side-by-side structure was not the first paranemic structure proposed. The first was the 1969 "straight-ladder" structure of Tai Te Wu [1] [20]. Both structures were published in Proceedings of the National Academy of Sciences, but, whereas the $\mathrm{Wu}$ structure attracted very little attention, the side-by-side structure aroused a small storm of controversy within the world community of DNA structural scientists. This perhaps was because of Rodley et al $s$ assertion that their DNA model was consistent with the original 1953 X-ray crystallogra- 


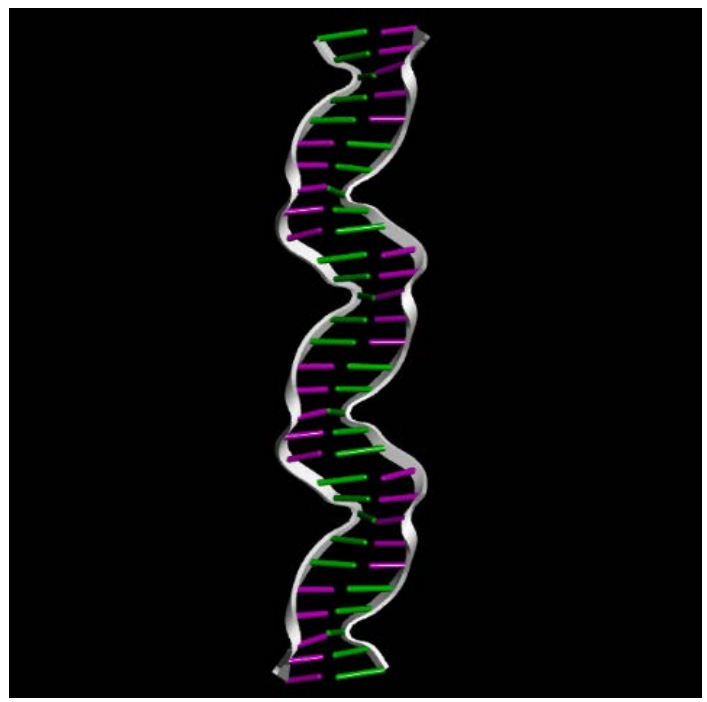

Figure 1. Rodley "side-by-side" structure [18]. The structure is based upon the "traditional" Watson-Crick structure, except that the direction of helical winding reverses every 5 base pairs, so that the net number of helical twists is zero. Since the strands therefore never fully cross one another, it would be possible, with only slight modification, for the structure to be circularized to yield a circular duplex with $L_{K}=0$, whose strands could be non-destructively separated by denaturation.

phy data of Wilkins and his associates [21], raising the possibility that side-by-side might be more than mere theory, but rather the structure of DNA in the real world generally.

The obvious next question was this: If native circular DNA is presumed to have the Rodley structure, which has $\mathrm{L}_{\mathrm{K}}=0$, why don't the strands separate upon alkali denaturation, as is the case with linear DNA? The answer Rodley proposed was that the circularity somehow gave rise to a structure which had the property that base-stacking alone was somehow sufficient to maintain the duplex structure, even after alkali denaturation, since the latter destroys only base pairing, not base stacking. That proposition was at least consistent with the known fact that base stacking is more important than base pairing in the maintenance of the DNA duplex structure [22].

To put the matter to rest, Crick publicly suggested the experiment that Stettler et al eventually did [9]. The design of the experiment was to be as follows.

- First, the strands of a plasmid chromosome should be destructively separated (the only way possible back then). This would require limited, controlled nicking by the non-discriminating enzyme DNase I, giving rise to a random mixture of nicked linear and intact circular strands.

- The strands should then be separated by alkali denaturation, and the surviving intact single-stranded circular DNA; a mixture of both "top" and "bottom" strands; should be separated from the nicked linear strands by sucrose velocity gradient centrifugation.

- Then the purified mixture of top and bottom strands should be reannealed into a new duplex. This duplex, by design, would be "side-by-side", i.e., paranemic, since nothing in the experimental protocol could possibly introduce 
a net helical twist where there was none.

The protocol is illustrated in Figure 2. The top row shows the actual experimental design, which was carried out by Stettler et al, and which did, in fact, gave rise to a duplex structure with no net helical twist. For comparison, the Watson-Crick structure is shown in the middle and bottom rows of the figure, which latter two rows are included only to illustrate the impossibility of a plectonemically-intertwined structure arising in this experiment.

For this work, Stettler et al used the native DNA of a $5 \mathrm{~kb}$ plasmid called $\mathrm{P} \beta \mathrm{G}$. After separating the strands, they reannealed them under the following conditions:

$$
\mathrm{pH} 8.5,60^{\circ}, 0.5 \underline{\mathrm{M} \mathrm{NaCl}}
$$

These conditions were presumably "borrowed" from the annals of linear DNA reannealing science. The question of whether these conditions were also adequate for circular DNA reannealing does not appear to have been asked by the authors. This question is more important than it might at first seem, as we shall see shortly. In any event, the reannealing did, in fact, give rise to a duplex structure.

Because the authors believed that the duplex product, created according to the Crick-suggested protocol outlined above, was a new, hitherto unknown DNA form, they gave it a new name, "Form V".

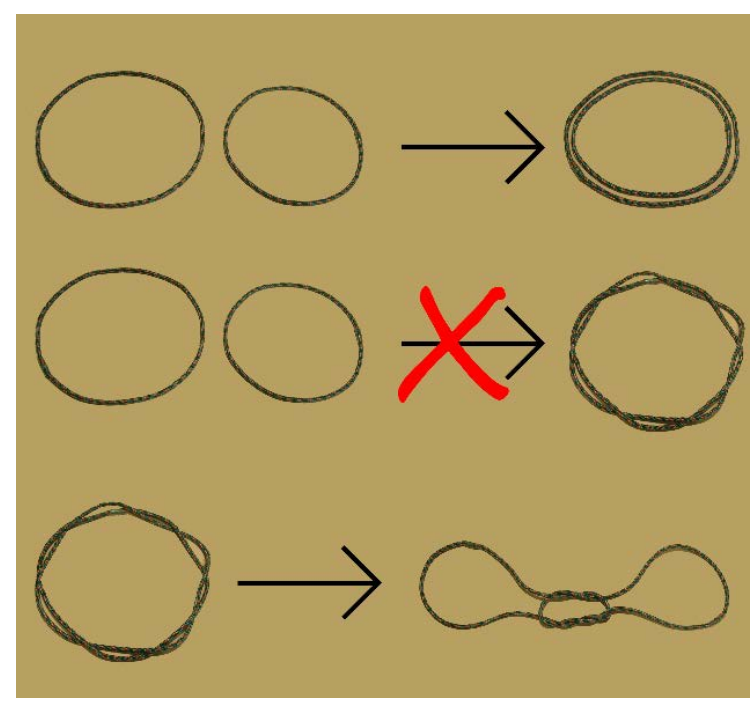

Figure 2. Photographs of actual rope models illustrating the design of the Weissmann experiment, as published in Stettler et al [9]. Top row: These workers separated the strands of a plasmid, then reannealed them at $\mathrm{pH} 8.5,60^{\circ}, 0.5 \underline{\mathrm{M} \mathrm{NaCl}}$. The experimental question was, "Will the product, which cannot have any net topological twists, have the same properties as native DNA, or not?" If the physical properties of the reaction product, illustrated in the top row, proved to be those of native DNA, then native DNA has no net topological twists. Middle row: This depicts an impossible reaction, where the separated strands reanneal to a Watson-Crick plectonemic (twisted) structure. That cannot have happened in this experiment, because there were no nicking-joining enzymes present, wherewith to create and lock in a twist. Bottom row: To dramatize the topological linkage between Watson-Crick circularized strands, this rope model illustrates what happens when one tries to separate them without breaking one of them open. 
The reannealed product was then examined by agarose gel electrophoresis (Figure 3). Lane 1 shows the electrophoresis pattern of the native $P \beta G$ chromosome. Like most plasmid chromosomes, it consists of two bands. The faster band is Form I, which is fully-intact, and hence superhelical (as are most naturally-occurring circular duplex chromosomes). This accounts for its faster rate of migration. The slower band is Form II; DNA which has become nicked. Even a single nick destroys the superhelical winding, causing the chromosome to "relax", which means to assume a more spread-out, "open circular" appearance. Form II thus presents a larger surface area to the agarose, which results in increased viscous drag, and hence a slower electrophoretic mobility.

Now let us look at Lanes $2 \& 3$, which show the electrophoretic patterns of two samples of the new "Form V" DNA. These lanes also display two bands. The Form II nicked band appears to be essentially the same as that which is seen in Lane 1. But the intact "Form V" bands migrate significantly more rapidly than the native Form I band in Lane 1. Forms I and "V" are therefore apparently not the same, although we cannot, of course, deduce the structure of either, merely from its electrophoretic mobility.

If we could somehow be confident that the Form I and "Form V" structures were not merely different conformers, interconvertible without breakage of covalent bonds, then we could say with confidence that the main point of the study had, at that point, already been made: "Form V" does not have the same structure as Form I native DNA. We know that the structure of "Form V" is the paranemic (and perhaps literally "side-by-side") structure of Gordon Rodley, because it was designed to be just that. Thus, Form I native DNA, having a signifi-

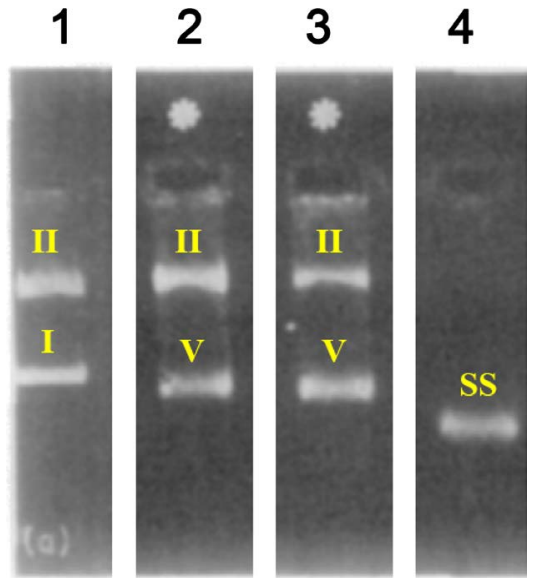

Figure 3. Gel electrophoresis of "Form V", adapted from Stettler et al [9]. The original figure contained 33 agarose lanes. To facilitate comprehension of the relevant results, we have used Photoshop to juxtapose the four lanes we need to consider, and have removed the other 29 lanes. Lane 1: The electrophoresis pattern for $\mathrm{P} \beta \mathrm{G}$ native DNA, showing Form I (i.e., native intact chromosomal DNA, which is superhelical) and Form II (i.e., Form I, relaxed by nicking). Lane $2 \&$ Lane 3: Two samples of $\mathrm{P} \beta \mathrm{G}$ DNA whose strands were separated, then reannealed at $\mathrm{pH} 8.5,60^{\circ}, 0.5 \mathrm{M} \mathrm{NaCl}$. Note that the Form II bands are parallel to that of Lane 1, but the bands corresponding to Form I in Lane 1 are here labeled "V", both of which moved slightly faster than Form I in the gel. Lane 4: P $\beta$ G single-stranded DNA, before reannealing. 
cantly different electrophoretic mobility, [apparently] cannot have the paranemic, side-by-side structure.

This was precisely the result that Crick sought, and, pending some strong argument to the contrary, it could have been assumed, at that point in time, that the Rodley side-by-side structure had been forever put to rest as a structure for DNA in the real world.

Nevertheless, the key question of whether "Form V" was truly based-paired, had to be addressed. For if it were to turn out that DNA, even in the absence of topological intertwining of the strands, was yet able to assume a stable duplex structure without base-pairing (since base-pairing is abolished by alkali denaturation), then the above-referenced confidence - i.e., that Form I and "Form V" were not merely different conformers of the same underlying structure - would be destroyed.

The possibility that - unbeknownst to the world - free circular single DNA strands in solution might be capable of forming a non-base-paired, stable duplex structure, therefore had to be ruled out. Toward this end, a control experiment was performed. The object of that experiment was to use DNA that could not possibly form canonical base-pairs, and to demonstrate, by using that DNA in a reannealing experiment employing the same conditions as the original experiment, that no "Form V" structure would appear. That would prove that "Form $\mathrm{V}$ " could only arise from complementary strands of DNA, the strong implication therefore being that "Form V" is a base-paired structure.

To execute this control experiment, Weissmann employed the virion chromosomal DNA of the bacteriophage $\phi x 174$, a popular research vehicle. $\phi x 174$ is one of a less-common group of viruses which package their DNA as a single strand. Since the complementary strand is not present in the virion, there is, in principle at least, no possibility of significant base-pairing when the virion single-stranded DNA is subjected to conditions of reannealing.

Stettler et al $s$ control experiment is shown in Figure 4. In Lane 1 we again see the native $\mathrm{P} \beta \mathrm{G}$ DNA. Let us skip momentarily past Lane 2 , and direct our attention to Lane 3. This is "Form V" DNA, taken originally from the experiment shown in Figure 3, but then subjected to formamide denaturation ( $90 \%$ formamide, $10 \underline{\mathrm{mM}}$ Tris $\cdot \mathrm{HCl}, \mathrm{pH} 8,80^{\circ}, 10$ minutes). This treatment brought about the dissociation of "Form $V$ " into single strands. This is an important result which we shall be returning to shortly. For now, however, we only need to note that the authors' purpose in including this lane was merely to establish an expected position for single-stranded DNA in the agarose gel.

A portion of the denatured $\mathrm{P} \beta \mathrm{G}$ DNA from Lane 3 was next subjected to reannealing. The reannealing conditions were radically different from those used in the experiment shown in Figure 3, for reasons which the authors never explained. These new conditions were:

$50 \%$ formamide, $0.05 \underline{\mathrm{M} \mathrm{NaCl}} 5 \underline{\mathrm{mM}}$ Tris $\cdot \mathrm{HCl}, \mathrm{pH} 8,20^{\circ} \mathrm{C}$, for 24 hours.

Note that, relative to the reannealing experiment shown in Figure 3, this one employs a different solvent, salt concentration, $\mathrm{pH}$, temperature, and reanneal- 


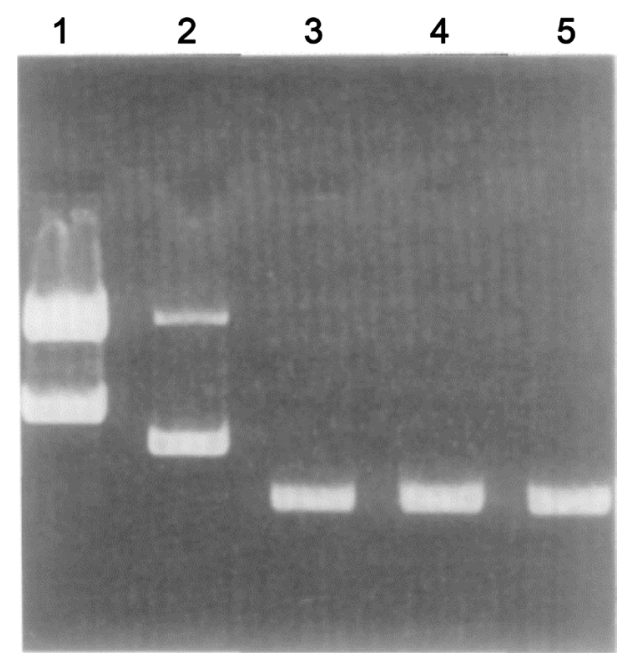

Figure 4. Agarose gel electrophoresis of "Form V" $\mathrm{P} \beta \mathrm{G}$ DNA and $\phi \mathrm{x} 174$ virion DNA. Adapted from Stettler et al, 1979 [9]. Lane 1: P $\beta$ G control DNA, showing the expected Form I and Form II bands. Lane 2 \& Lane 3: P $\beta$ G experimental DNA. Lane 3 is the "Form V" DNA shown in Figure 3, after denaturation in $90 \%$ formamide, $10 \mathrm{mM}$ Tris $\cdot \mathrm{HCl}(\mathrm{pH}$ 8) for $10 \mathrm{~min}$ at $80^{\circ} \mathrm{C}$, causing it to revert to single strands. Lane 2 is the denatured DNA from Lane 3, after reannealing for $24 \mathrm{~h}$ at $20^{\circ} \mathrm{C}$ in $50 \%$ formamide, $0.05 \mathrm{M} \mathrm{NaCl}, 5 \mathrm{mM}$ Tris. $\mathrm{HCl}(\mathrm{pH}$ 8). This restores the "Form V" electrophoresis pattern we saw in Figure 3, Lanes 2 and 3. Lanes 4 \& 5: Single-stranded $\phi \times 174$ control DNA. In Lane 5 the $\phi \times 174$ DNA was denatured by the same $90 \%$ formamide-based protocol as was used for the $\mathrm{P} \beta \mathrm{G}$ DNA in Lane 3. In Lane 4 the $\phi x 174$ DNA from Lane 5 was reannealed by the same $50 \%$ formamide-based protocol as was used for the $\mathrm{P} \beta \mathrm{G}$ DNA in Lane 2. It is apparent that, under the conditions of this experiment, $\mathrm{P} \beta \mathrm{G}$ DNA can be reannealed to a duplex form, but $\phi \times 174$ cannot.

ing time. I find these discrepancies somewhat disturbing, since Figure 4 presents what is supposed to be a control for the experiment in Figure 3. But since the control experiment in Figure 4 is self-sufficient as presented, there is perhaps no need to dwell upon this.

The reannealing (Figure 4) of the DNA from Lane 3 resulted in the banding pattern seen in Lane 2. A comparison of Lanes 1 and 2 here, with Lanes 1-3 in Figure 3, would appear to confirm that this reannealing has restored the duplex "Form V" structure.

Now let us examine the last two lanes of Figure 4. Lane 5 shows the $\phi \times 174$ single-stranded virion control DNA, after being subjected to the same $90 \%$ formamide-based denaturation protocol used to generate the DNA seen in Lane 3. This of course was not strictly necessary, since the $\phi x 174$ DNA was already single-stranded, but this was, after all, a control experiment. This same control DNA was then reannealed, employing the same $50 \%$ formamide-based protocol used to generate the reannealed DNA seen in Lane 2. Note, however, that whereas the single-stranded P $\beta$ G DNA (Lane 3) could be reannealed to "Form V" (Lane 2), the single-stranded $\phi x 174$ control DNA (Lane 5) could not be reannealed to a duplex form (Lane 4 ).

Since the only difference between the DNA in Lanes 3 and 5 was that Lane 3 contained complementary DNA, whereas Lane 5 contained only single-stranded 
$\phi x 174$ virion DNA, we are apparently compelled to the conclusion that "Form V" cannot appear in the absence of canonical, complementary base-pairing.

If all this is true and correct, then Weissmann's thesis is entirely proved: "Form V" is a base-paired, topologically non-helical duplex, presumably in a "side-by-side" conformation, and its properties distinguish it sufficiently from Form I that we may conclusively dismiss the "side-by-side" structure as a structure for naturally-occurring DNA in the real world.

This publication was a great victory for Crick, because it appeared to validate the Watson-Crick structure for all DNA, and to invalidate any topologically-non-helical competitor. Unfortunately, there were two very serious problems with the Stettler et al experiment we have just reviewed:

1) the reannealing conditions used to create "Form V", which was ostensibly base-paired, were conditions known to be incapable of producing a base-paired structure, and

2) the control experiment, to prove that complementary DNA was necessary for reannealing, was defective, because it employed a DNA with a tendency to self-anneal.

Let us look at these problems more closely.

With respect to the first serious problem, we need to bring back to mind Weissmann's reannealing conditions, wherewith he created "Form V":

$\mathrm{pH} 8.5,60^{\circ}, 0.5 \underline{\mathrm{M} \mathrm{NaCl}}$

It was essential to Weissmann's thesis that this reannealing result in a base-paired structure. I shall now explain why I believe that these conditions cannot possibly have succeeded in doing that.

To the best of my knowledge, no one except Weissmann has ever reported on the reannealing of previously-separated, complementary circular single strands. There were, however, a number of papers on the reannealing of the alkali-denatured duplex structure, i.e., Form IV, during the period 1963-1981 (of which references [4], [5] and [6] are examples). I believe the mechanics of reannealing to be similar in both cases, that is, whether one starts from previously-separated single strands, or starts from Form IV, which is duplex. This I say because when one starts from separate single strands, the first thing that must happen is that each strand must meet its complementary strand, and form a rudimentary duplex. This would be a metastable, or transitional structure which was, structurally-speaking, "pluripotent", that is, although inherently unstable, it would nevertheless be capable of giving rise to at least three other, stable structures:

- It could revert to single-stranded DNA.

- It could morph into Form I.

- It could morph into Form IV.

For the sake of the discussion, I have arbitrarily designated this metastable form "Form 0".

In order for Form 0 to transition to Form I, which is base-paired, it must be that the strands of Form 0, although loosely-associated, are able to rotate with 
respect to one another, for if they did not do that, then complementary base-pairing could not be restored. This argument is illustrated in reference [23].

One could argue against the existence of Form 0 , alleging instead that reannealing occurs only when two previously-separated single strands just happen to coincidentally encounter one another in a properly base-paired alignment, which, for a $5000 \mathrm{bp}$ chromosome, would occur at the very plausible frequency of 1-in-5000 encounters. But that seems to be a rather unlikely explanation for reannealing, since if nothing more is required for reannealing than a favorably-oriented chance encounter of the two complementary strands, then the reannealing of those strands should happen under any and all conditions of $\mathrm{pH}$, temperature and ionic strength, which is not the case. Therefore I propose that the metastable transitional Form 0, and the ensuing strand rotation, must exist.

How does this mechanism of single strand reannealing differ from the reannealing of Form IV? Probably not much. Since Form IV is stable under nearly all conditions except those few sets of conditions where reannealing has been shown to occur at a finite rate, it follows that the two strands of Form IV are ordinarily locked into some sort of non-base-paired conformation, which needs to be disrupted if reannealing is to take place. Whatever intermediate steps may or may not be involved in Form IV reannealing, it is intuitively obvious that the $f i$ nal step must involve a state in which the strands are able to rotate with respect to one another, for if they did not do that, then complementary base-pairing could not be restored.

Thus, the rate-limiting step in reannealing - the mutual rotation necessary to reestablish complementary base pairing - is very likely the same, whether starting with separated single strands, or starting with the duplex Form IV chromosome.

If in fact the reannealing of separate single strands is not very different than the reannealing of Form IV, then the constraints known and repeatedly demonstrated for reannealing of Form IV, with respect to the need for pinpoint control of $\mathrm{pH}$, temperature and ionic strength [4] [5] [6], must also pertain to the reannealing of circular DNA when starting from single strands.

Proceeding from this argument, we now turn to the data on percent reannealing of Form IV, i.e., renaturation of the denatured Form IV back to the native Form I, as a function of $\mathrm{pH}$, temperature and ionic strength, from the laboratory of Strider and Warner [4] [5] [6]. We look here only at the curve for $60^{\circ}$, because that was precisely the temperature employed several years later by Stettler et al, for their creation of "Form V" (Figure 5).

The black curve is the actual Strider-Warner reannealing data for $\phi x 174$ Form IV at $60^{\circ}$. Note that the percent conversion back to Form I was maximum at about $\mathrm{pH} 11$, at which reannealing was nearly $100 \%$ after 10 minutes. Strider and Warner published a large number of such reannealing curves, in experiments where either the $\mathrm{pH}$, temperature or ionic strength was systematically varied, and they all have the same general shape. I am therefore surely justified in adding the orange extrapolation lines shown in the figure, which show that at $\mathrm{pH}$ 


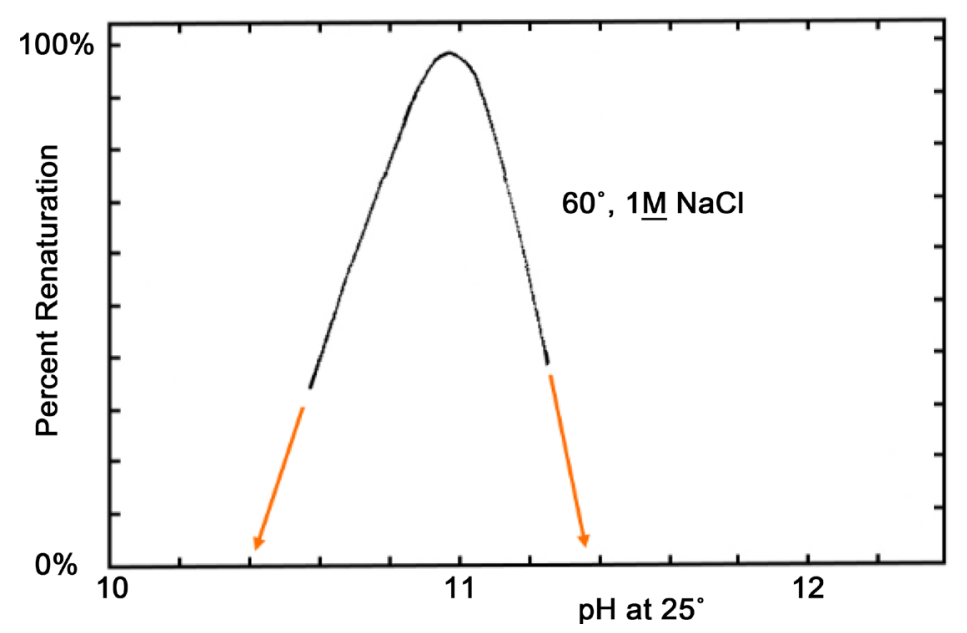

Figure 5. Efficiency of renaturation of Form IV (denatured DNA) back to Form I (native

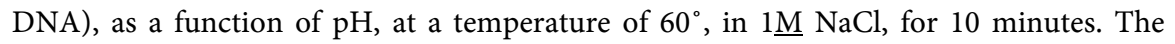
DNA used was $\phi \times 174$ replicative form ("RF"). Adapted from data in both Strider 1971, Figure 5 (reference [4]) and Strider \& Warner 1981, Figure 2 (reference [6]). Renaturation was nearly $100 \%$ at about $\mathrm{pH} 11$, dropping off to about $35 \%$ at $\mathrm{pH} 10.6$. Extrapolation (orange arrows) suggests that a further drop of only $0.2 \mathrm{pH}$ units (i.e., to $\mathrm{pH} 10.4$ ) would abolish all reannealing under these conditions. At Stettler et als reannealing $\mathrm{pH}$ of 8.5 (reference [9]), two entire $\mathrm{pH}$ units below the zero-reannealing point indicated by the orange arrows, it is highly-doubtful that any base-paired DNA could have been obtained.

10.4, the percent reannealing would have dropped to zero.

Now let us apply these data to "Form V". In order to create "Form V", Weissmann reannealed his $\mathrm{P} \beta \mathrm{G}$ DNA at $\mathrm{pH}$ 8.5. But that's about two entire $\mathrm{pH}$ points below the Strider zero-reannealing $\mathrm{pH}$ (Figure 5)! If I'm right, and if reannealing from single strands is subject to the same limitations as reannealing from Form IV, then Weissmann cannot possibly have created a base-paired structure at $p H 8.5$, two $p H$ units below the zero reannealing point. He can only have created Form IV, which, although difficult to reanneal, is nevertheless very easy to make, appearing readily in the presence of various denaturants, and, once formed, being subsequently stable throughout the $\mathrm{pH}$ scale.

In other words, I am positing that single-stranded circular DNA, due to the unique topological constraints imposed by its circularity, can do something that single-stranded linear DNA cannot do: form a stable duplex structure which is not stabilized by complementary base pairing. This structure is fully elucidated in references [7] and [8], which show exactly how it forms, what holds it together, and why its compactness increases $200 \%-300 \%$ at high $\mathrm{pH}$.

Weissmann, in contemplating the structure and nature of his supposedly-novel "Form V", should have considered the possibility that it wasn't a "new" form of DNA at all, but merely Form IV. Apparently, however, he didn't consider that possibility. Why not? Probably because his "Form V" was only slightly more compact than Form I (as shown in Figure 3 \& Figure 4), whereas Form IV, in most of the studies published during the years 1963-1981, was portrayed as being immensely more compact, sedimenting 200\% - 300\% faster than Form I in velocity gradient ultracentrifugation. This is illustrated in Figure 6. 


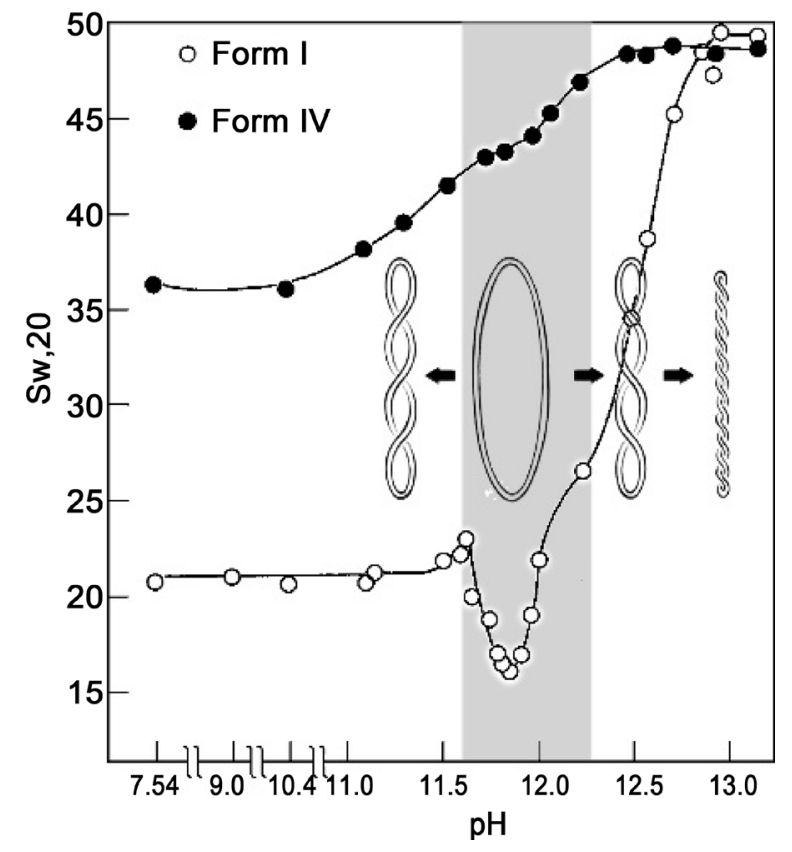

Figure 6. Velocity sedimentation coefficient $(S)$ vs. $\mathrm{pH}$ titration of the duplex replicative

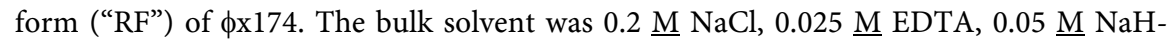
$\mathrm{CO} 3$, i.e., over $0.2 \underline{\mathrm{M}}$ salt. At $\mathrm{pH} 13$, the additional salt added, in the form of $\mathrm{NaOH}$, caused the $[\mathrm{Na}+]$ concentration to rise to about $0.4 \underline{\mathrm{M}}$. The drawings above the lower curve apocryphally-indicate the state of superhelical twisting as a function of $\mathrm{pH}$. Note that for graphic clarity, no secondary helical twisting is shown; the drawings are only meant to illustrate tertiary (superhelical) twisting. At pHs below 11.8, the supertwisting is right-handed ("negative"); above that $\mathrm{pH}$ the winding sense reverses, and becomes left-handed ("positive"). At pH 11.8 there is no superhelical winding; the chromosome is an "open circle", whose larger surface area causes $S$ to drop to a minimum. The lower curve (o-o-o) shows the stages in denaturation, culminating at $\mathrm{pH} 13$ with an approx-

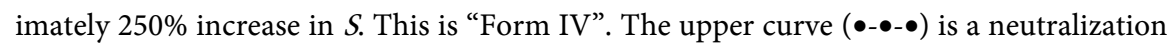
curve for the Form IV. Note that even when the $\mathrm{pH}$ has been restored to neutrality, i.e., $\mathrm{pH} 7$, the sedimentation coefficient has not returned to the native $21 s$, but remains quite elevated, at about $36 \mathrm{~s}$, midway between the native form and the maximally-compact $50 \mathrm{~s}$ form seen at $\mathrm{pH} 13$.

Figure 6 shows an alkali denaturation experiment at the relatively high salt concentration of $0.2-0.4 \underline{\mathrm{M}}$, from the laboratory of Rush and Warner [10]. As the $\mathrm{pH}$ increased from 7 to 13 , the sedimentation coefficient of $\phi x 174$ RF shot up from $21 s$ to about $50 s$. The $50 s$ form is Form IV.

Weissmann, the senior author of Stettler et al [9], had in previous years been a colleague of Rush in the biochemistry department of the New York University School of Medicine, and was well-aware of Rush's data. He therefore would have had every reason to expect, in his own electrophoretic analysis of the ostensibly-new DNA form he had created, a comparable 200\% - 300\% increase in electrophoretic mobility, if his new DNA form had been Form IV. But because he only saw a slight increase in electrophoretic mobility, i.e., nowhere near $200 \%$ $300 \%$ (compare Form IV in Figure 6 with "Form V” in Figure 3 \& Figure 4), he rejected the possibility that his new DNA form was Form IV, concluding rather that it was a hitherto unknown form, and naming it "Form V". 
That conclusion may have been premature.

A little-known publication from the laboratory of Pouwels et al [24] (Figure $7)$, revealed that the sedimentation coefficient, i.e., the compactness, of $\phi \times 174$ Form IV was markedly altered by changes in salt concentration. It was true that at the relatively high peak salt concentration of the experiment in Figure 6, i.e., $0.4 \underline{\mathrm{M} \mathrm{NaCl}}$, the $s$ value of $\phi \times 174 \mathrm{DNA}$ in the Figure 7 data was substantially elevated (about $35 s$, not quite the $50 s$ seen in Figure 6, suggesting that the larger $s$ value in Figure 6 also required a $\mathrm{pH}$ of 13). But, at the low salt concentration of a typical agarose gel (marked by the double-headed arrow in Figure 7), Form IV, although still more compact than Form I, was only slightly more compact, not $200 \%$ - 300\% more compact, because such elevated $s$ values require much higher salt concentrations than those typically found in agarose gels.

In other words, the slight increase in electrophoretic mobility of "Form V" relative to Form I, as seen in Figure 3 and Figure 4, was fully-consistent with the conclusion that "Form V" was really Form IV, even though Weissmann and associates had presumptuously ruled that out.

Because of the following two deficiencies:

1) The duplex structure Weissmann created was created at a $\mathrm{pH}$ at which a base-paired structure cannot likely have appeared, and

2) he made no effort to rule out that his reannealed structure was merely Form IV...

...I would propose, with considerable certainty, that his reannealing, of the separated single strands of $\mathrm{P} \beta \mathrm{G}$, produced the well-known and extensively-characterized duplex structure, Form IV, and not the supposedly-novel, hitherto-unknown "Form V".

In fact, I doubt that "Form V" even exists - I believe that it is merely Form IV, created under reannealing conditions which were seriously insufficient for the reestablishment of the native base-paired duplex structure.

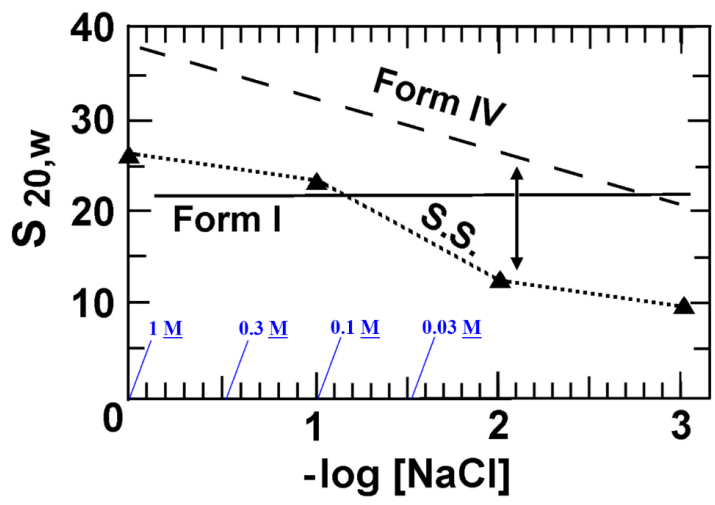

Figure 7. Dependence of the sedimentation coefficient $S$ of $\phi x 174$ Form IV on salt concentration. This dependence is approximately linear, when plotted against $-\log [\mathrm{NaCl}]$. Form I native DNA shows no dependence upon salt concentration in this range. "S.S." is single-stranded $\phi x 174$ virion DNA. The double-headed arrow marks the approximate salt concentration in a typical agarose gel. The blue figures at the bottom are suggested salt concentrations to be used for the establishment of an $S$ vs. [ $\mathrm{NaCl}]$ "fingerprint", as described in the text. Adapted from Pouwels et al. [24]. 
But what about his control experiment? That was the second serious problem alluded to earlier. I have just alleged that when Weissmann reannealed the experimental $\mathrm{P} \beta \mathrm{G}$ single strands, he produced an anomalous, non-base-paired duplex, i.e., Form IV (="Form V"), which suggests that any size-matched circular single-stranded DNA could do the same, whether or not the strands were complementary. Yet Weissmann's control experiment was alleged to have proven that the "Form V" duplex structure cannot appear in the absence of canonical Watson-Crick base-pairing!

That is, the control DNA, from the virion of $\phi x 174$, which includes only one of the two strands, could not be reannealed to a duplex form. From this he concluded that not only is "Form V" base-paired, but that it cannot appear in the absence of base-pairing.

To re-state this, I am alleging that "Form V" is not base-paired, but is really the non-base-paired structure known as Form IV, whereas Weissmann is alleging that "Form V" not only is base-paired, but absolutely requires complementary base-pairing if it is to appear at all! We cannot both be right!

This irreconcilable difference of opinion is reconciled by a more thoughtful consideration of the DNA used in the control experiment. That experiment was, on its face, well-conceived and executed, but it unfortunately failed to take into account certain known characteristics of the control DNA. $\phi x 174$ is one of a growing class of known but less-common species of viruses whose chromosomes are packaged as a single strand. Some such viruses have a single-stranded DNA chromosome, others have an RNA chromosome. The best-known of all the RNA viruses is the Tobacco Mosaic Virus, which has been intensely studied for about a century now.

It is well-known that the chromosomes of these viruses behave, structurally-speaking, like transfer RNA. That is, they have a highly-significant intra-strand hydrogen bonding pattern, which is necessary to induce the precise conformation required for packaging the single-stranded chromosome into the virus capsid. When exposed to $90 \%$ formamide, they will open up into an extended random coil, with no base-pairing. But when simply placed into an agarose gel, in which the $90 \%$ formamide will be immediately diluted out, they will revert back to their t-RNA-like structure, with intra-strand hydrogen bonding. That is what we're looking at in Figure 4, Lane 5 - ordinary $\phi x 174$ singlestranded virion DNA, in its usual t-RNA-like conformation, with intra-strand hydrogen-bonding, ready for packaging in the virion.

Likewise, when reannealed in 50\% formamide (Figure 4, Lane 4), the $\phi \times 174$ single-stranded chromosomes will also surely resume their t-RNA-like structure, with intra-strand hydrogen-bonding. That is almost certainly why in Figure 4, Lanes 4 and 5 are the same - they are both native $\phi x 174$ single-stranded DNA, with the same intra-strand hydrogen bonding that is seen in the virion capsid.

But how can we be sure that one $\phi x 174$ virion single strand could not also form a duplex structure with another $\phi x 174$ virion single strand? After all, we are proposing that "Form V" is really Form IV, a non-base-paired duplex. Why 
couldn't $\phi x 174$ single-stranded virion DNA also form a non-base-paired duplex, by reannealing with itself?

In order to understand why not, we need to think the matter through logically. Let us consider, for a moment, the process of formation of $\phi x 174$ 's intra-strand hydrogen bonds. The process of forming those bonds is surely cooperative, with each additional intra-strand hydrogen bond further facilitating the formation of the next one, so that the final conformation, necessary for packing in the virus capsid, is quickly attained. But that is an intra-strand process. What would be expected to happen if one of the $\phi x 174$ single-stranded chromosomes encountered another one in the $50 \%$ formamide reannealing bath?

Probably nothing. Presumably a few inter-strand hydrogen bonds might anomalously form. But an inter-strand hydrogen bond would likely be a structural "dead end"; that is, whatever duplex structure would be theoretically possible, as a result of such a chance 2-strand encounter, would be competing with the normal intra-strand folding process. Since the intra-strand, t-RNA-like structure is, by teleologic design, energetically-superior to any random structure likely to form from chance association of two of the like single-strands in solution, it follows that the intra-strand, t-RNA-like structure is the one we'll see, not the duplex structure resulting from random association of pairs of $\phi x 174$ single-stranded virion chromosomes.

Speaking anthropomorphically, we may re-state this as follows: The chromosome of a virus that packages only a single strand in the capsid, when denatured and then reannealed, will "prefer" to reanneal with itself, to give its normal t-RNA-like structure, rather than to reanneal with a second copy of itself, where that t-RNA-like structure cannot possibly form.

In other words, the use of the chromosome of a virus whose DNA is packaged as a single, t-RNA-like single strand, was an unfortunate choice for a control experiment, because it rendered the control experiment null and void.

Assuming that my views of Weissmann's actual experiment and control experiment are valid, we must conclude that the Weissmann experiment - designed to test the question "Does native circular DNA really have a helical twist?" - was ultimately of no value at all in answering the question, and can be dismissed in its entirety.

While this is a bleak and depressing conclusion, the fact of the matter is that this is a "cloud with a silver lining". If I have explained all of this with sufficient clarity, then you now know that Weissmann has inadvertently shown us the way to non-destructively separate the strands of a plasmid, something that no one but Tai Te Wu has ever done [1]. It's the 2-step process which I presented at the beginning of the present manuscript: 1) First we must alkali-denature the plasmid at $\mathrm{pH} \mathrm{13,} \mathrm{which} \mathrm{produces} \mathrm{Form} \mathrm{IV,} \mathrm{as} \mathrm{has} \mathrm{been} \mathrm{known} \mathrm{for} \mathrm{at} \mathrm{least} \mathrm{a}$ half-century. But Form IV, while not base-paired, is persistently duplex. 2) Next we must further denature the Form IV to its component single strands. Weissmann, in Figure 4, Lane 3, showed us how to readily accomplish this, employing $90 \%$ formamide for the denaturation. 
It might be protested that if formamide could do this, then it would have been apparent decades ago, since many DNA denaturation studies were done in the 1950s and 1960s. But the only published study I was able to unearth, in which formamide was used to attempt the denaturation of circular DNA, apparently showed that irreversible denaturation (i.e., denaturation to Form IV) could not be attained by formamide alone [3]. The two-step process outlined here is therefore necessary.

\section{Second Experiment: Reannealing of the Previously- Separated Strands of a Duplex Circular Plasmid}

What follows is a concise description of the experiment which will bring about the reannealing of the separated strands of a plasmid, to reconstitute the original duplex chromosome, with all its physical properties restored. A detailed protocol will be posted at https://NotAHelix.net, upon publication of this manuscript.

\subsection{Historical Background}

This second experiment - reannealing of the separated single strands - is more sure than the first, because it has already been done, and the outcome is therefore almost certain. But the second experiment requires a few enzymes which most labs will not have, and which must therefore be purchased. Moreover, the second experiment could take several days to complete, depending upon the skill and experience of the researcher, whereas the first experiment - the separation of the strands - can be done by almost anyone, in literally a few minutes. Therefore I listed the separation protocol first in this manuscript.

The theory and rationale behind the second experiment was already stated above, in the report on the work of Weissmann and his co-workers (Stettler et a) [9], who reannealed the separated strands of a plasmid, and reported the resulting duplex to be abnormal in its physical properties. The reasons why the experiment - in the manner in which they did it - cannot be taken seriously were given above.

But it turns out that Weissmann was not the only man doing the experiment. In that same year, 1979, Robert W. Chambers, who was at that time chairman of the New York University School of Medicine Department of Biochemistry, endeavored to perform the very same experiment. Weissmann, until a few years earlier, had been a professor in that same department, and the two of them, in response to Crick's public suggestion, were actually competing to get the experiment published first.

Chambers' version of the experiment employed the $\phi x 174$ RF ("replicative form") chromosome, which is duplex. He began by separating the strands of the $\mathrm{RF}$, which was, in those days, a laborious process. Shortly thereafter, the Weissmann paper was published, and Chambers, having lost the race for publication, discontinued work on the project, and retired his separated single strands of $\phi x 174 \mathrm{RF}$ to the refrigerator.

Later, however, Chambers stumbled across a totally unexpected phenomenon: 
the separated single strands of the RF, after merely co-incubating in the refrigerator, had self-assembled into a duplex with the same physical properties as the native chromosome, sedimenting in the Beckman Model E analytical ultracentrifuge as a single band at $21 s$ ([25] [26]). The implication is that the native duplex chromosome can be recreated from its separated strands by simple reannealing, under conditions where no helical twist can be introduced, suggesting that native DNA has no net helical twist. Note that this is exactly and precisely the opposite of what Weissmann had reported.

The Chambers discovery cannot have resulted from spontaneous strand breakage and repair, since, thermodynamically-speaking, a system within which strands are spontaneously breaking (which is a well-known phenomenon, dreaded by all DNA workers), cannot also be a system within which those same strands are spontaneously re-sealing themselves. Even if one were to surmise that spontaneous strand breakage and repair were analogous to the action of the enzyme topoisomerase, which requires no energy source, and which both breaks and re-seals DNA, there's still the question of Chambers' observation of a single band sedimenting at $21 \mathrm{~s}$. Spontaneous strand breakage and rejoining, by analogy to the action of topoisomerase, cannot possibly yield a single pure topoisomer, least of all the native topoisomer, which is the most highly-supertwisted of them all, and therefore the least likely to appear. In the thermodynamically-absurd hypothetical situation where totally-spontaneous strand breakage and repair were occurring with equal frequency, what would have to result would be the complete set of topoisomers for $\phi x 174$, about 25 in all. This set of topoisomers, depending upon the conditions of the analytical ultracentrifugation, would have sedimented as either 25 distinct bands, or else one very broad, wholly-unnatural-looking pseudo-band.

For reasons which are partly comprehensible, and partly incomprehensible, Chambers elected both to not publish this, and to not pursue it further. Therefore, at the present late date in molecular biological history, it is utterly essential that this experiment be repeated. Forty years ago, when the work was originally done, the experiment took months of hard labor, and cost a great deal of money. Today, employing "nicking enzymes", the work can be done in as little as a single day, at a cost of not more than about $\$ 1000$.

\subsection{Experimental Protocol}

\subsubsection{Isolation of the Single Strands of the Chromosome}

We start by isolating the separated strands of the chromosome. To accomplish this, we shall take advantage of the pairs of semi-synthetic "nicking" enzymes (i.e., site-specific, strand-specific nucleases) which are now readily available. These enzymes introduce a nick to a duplex circular plasmid chromosome at a single site, and on one strand only. This strand, once nicked, can then be digested by exonucleases such as exonuclease III, which only acts upon a free end, yielding a pure population of single-stranded, fully-intact circular DNA from the other strand of the chromosome only. If we were to start with the nicking en- 
zyme specific for the "top" strand, yielding a pure population of "bottom" strand DNA, the entire process could then be repeated with the sister nicking enzyme specific for the "bottom" strand, yielding, a pure population of "top" strand DNA.

(The terms "top" and "bottom" strands usually correspond to the "sense" and "antisense" strands of the chromosome, also sometimes referred to as "+" and “_" strands.)

Figure 8 depicts the plasmid pBR322, which has a single recognition site for each of the "sister" nicking enzymes Nt.BbvCI and N $\underline{b}$.BbvCI. The second letters of these otherwise-meaningless-looking enzyme names identify the strands upon

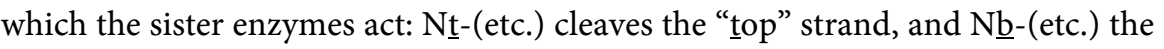
"bottom strand". In the drawing, we have distinguished between the two strands by coloring the recognition sites for the enzymes blue and red, respectively. The action of the single-stranded exonuclease, exonuclease III, is represented by a little "PacMan" figure:

There are hundreds, perhaps thousands of laboratories with access to these enzymes, and the reader might be wondering why someone hasn't intentionally, or even accidentally re-annealed these strands already. The answer was alluded to in the present manuscript, in the discussion above: re-annealing of denatured circular DNA is an exceedingly exact science, requiring precise adjustment of DNA concentration, $\mathrm{pH}$, ionic strength and temperature [4] [5] [6]. Unless the researcher is very familiar with the literature on this subject - and almost no re-

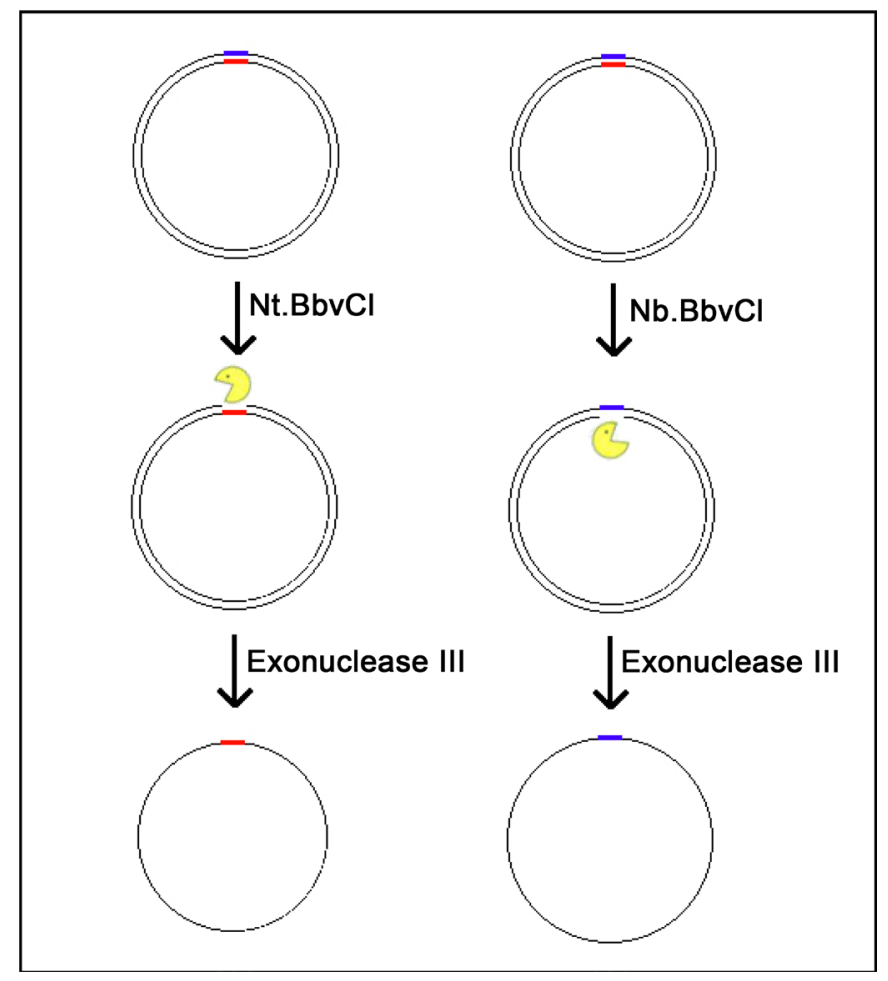

Figure 8. Creation of pure populations of single-stranded "top" and "bottom" strands from the chromosome of the plasmid pBR322, by the use of nicking enzymes and exonuclease iii. 
searchers living today possess such familiarity - any deviation from those parameters will result in reannealing only to Form IV, the non-base-paired, anomalous duplex we spoke of extensively in the previous section.

We shall, of course, employ the correct reannealing parameters, taken from the work of Strider \& Warner [4] [5] [6]. These authors identified a number of reannealing optima, mostly in $1 \underline{\mathrm{M} \mathrm{NaCl}}$. A good example, employing moderate conditions of reannealing, would be $70^{\circ}$, at which temperature and salt concentration the $\mathrm{pH}$ of optimal reannealing would be about 10.75 (see Section 3.2.3).

Once the DNA has been properly re-annealed, it shall be subjected to agarose gel electrophoresis in the presence of various concentrations of ethidium bromide, with native DNA as a control.

\subsubsection{Electrophoresis of the Reconstituted Duplex Circular Chromosome-"Ethidium Bromide Fingerprint"}

The fluorescent dye ethidium bromide ( $\mathrm{EtBr}$ ), an intercalating agent, has a marked effect on the electrophoretic mobility of native DNA (Form I), because it changes the superhelical winding in a very precise and predictable way.

Figure 9 depicts a hypothetical set of agarose gels, with ethidium bromide concentrations ranging from none (Lane A) to about $1.0 \mu \mathrm{g} / \mathrm{ml}$ (Lane G). Each gel has a pair of bands: a more-rapidly migrating Form I band, and a slower-moving control band consisting of Form II (nicked, i.e., "relaxed" DNA).

Because Form II is nicked, and because even a single nick destroys all the topological properties of the native chromosome, Form II is therefore not significantly affected by EtBr. Form I, on the other hand, is markedly affected. Form I is isolated in nature as a compact, right-handed, interwound superhelix. In the language of DNA topology, a right-handed superhelix is described as having a "negative" tertiary winding. The superhelical winding confers upon it a relatively rapid electrophoretic mobility, compared to its relaxed Form II "cousin". As depicted schematically in Lanes B-D, however [Figure 9], progressive increase in the EtBr concentration causes a progressive relaxation of the Form I chromosome, as the supertwists are unwound [27].

In Lane D, typically representing an EtBr concentration of about $0.2 \mu \mathrm{g} / \mathrm{ml}$, all supertwists are gone, and Forms I \& II co-migrate in the gel (the little space between the Form I and Form II bands is included only for graphic clarity).

At higher concentrations of EtBr (Lanes E-G), Form I once again becomes supertwisted, but now in the opposite, or left-handed ("positive") sense, with eventual complete restoration of the original compactness and fast electrophoretic mobility (Lane G). Although not shown in the figure, further increases in $\mathrm{EtBr}$, above $1 \mu \mathrm{g} / \mathrm{ml}$, do not bring about further increases in the electrophoretic mobility of Form I.

I shall refer to this pattern of changing electrophoretic mobility, in the presence of varying concentrations of $\mathrm{EtBr}$, as an "ethidium bromide fingerprint", since it uniquely identifies a species of DNA as being Form I. That is, although it is possible to imagine some non-Form-I DNA conformer, at some particular 


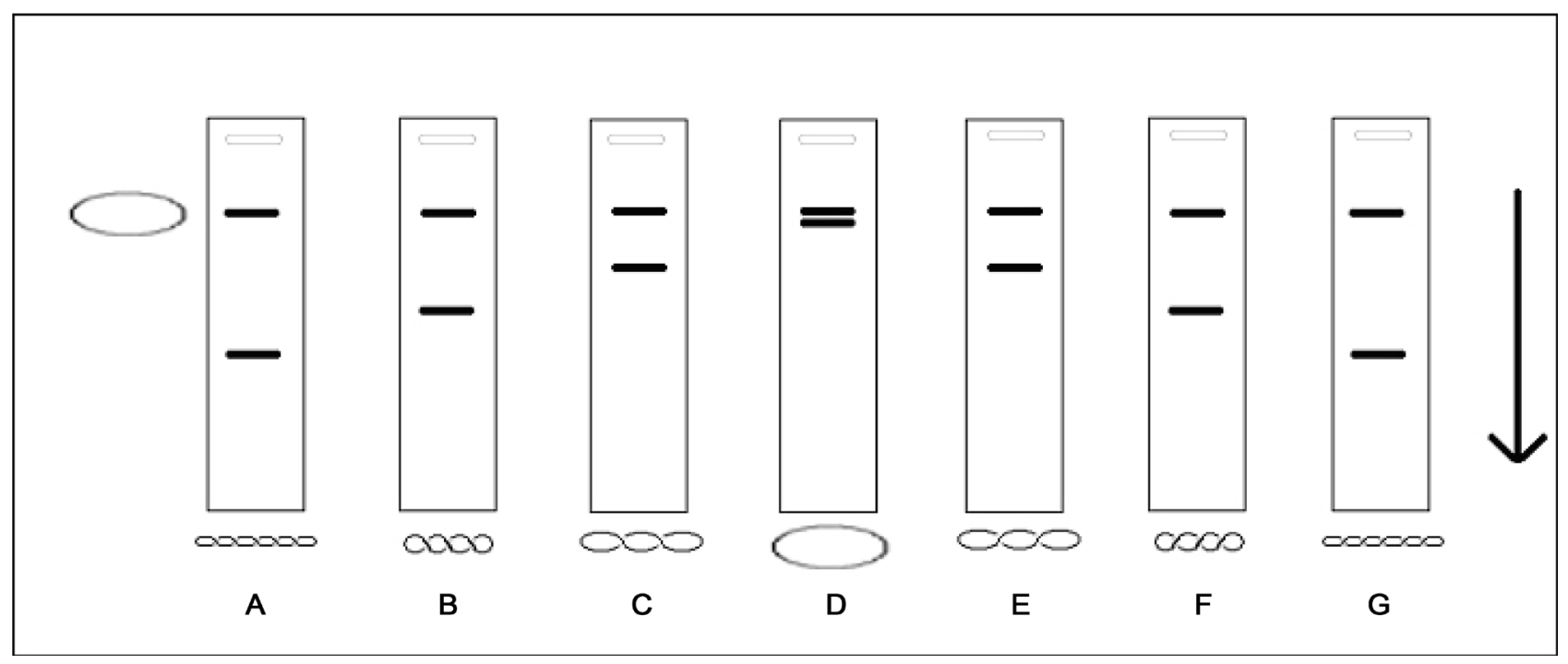

Figure 9. Agarose gel electrophoresis of Form I (native, superhelical) and Form II (nicked, "relaxed") duplex circular DNA in the presence of increasing concentrations of the intercalating agent, ethidium bromide (EtBr) in the agarose gel. The large arrow depicts the direction of migration in the electric field. The EtBr concentration increases to the right, from $0 \mu \mathrm{g} / \mathrm{ml}$ in $\mathrm{Lane} \mathrm{A}$, to about $1 \mu \mathrm{g} / \mathrm{ml}$ in Lane G. Lane D, containing the fully-relaxed conformer of Form I, typically involves EtBr concentrations of about $0.2 \mu \mathrm{g} / \mathrm{ml}$. Each of the gels, A-G, contain two bands of DNA, corresponding to Forms I \& II respectively. The Form I band is always faster. The position of the slower Form II band is not affected by EtBr. The little oval, on the extreme left of the drawing, schematically represents the simple, open-circular tertiary structure of Form II. Form I, on the other hand, is markedly affected by EtBr. The little drawings on the bottom of each lane schematically represent the tertiary structure of Form I. In the absence of EtBr (Lane A), Form I is a relatively tightly-wound, right-handed (or "negative") superhelix. Because of its compactness, it migrates significantly faster than its relaxed Form II "cousin". As the EtBr concentration is increased (Lanes B-D), the supertwists are progressively unwound, with a concomitant decrease in the electrophoretic mobility, until the Form I chromosome relaxes entirely (D). At that point, which typically occurs at $\mathrm{EtBr}$ concentrations around $0.2 \mu \mathrm{g} / \mathrm{ml}$, the tertiary conformation of Form I, and hence its electrophoretic mobility, are the same as that of Form II (for graphic clarity, a small space has been left between the Form I and Form II bands). At higher concentrations of EtBr (E-G), supertwists in the opposite sense (i.e., left-handed or "positive" supertwists) progressively appear in Form I, with concomitant increasing of the electrophoretic mobility. This increase continues up to EtBr concentrations of about $1 \mu \mathrm{g} / \mathrm{ml}$ (Lane G), at which point the Form I chromosome exhibits about the same compactness (and hence electrophoretic mobility) as the native structure in the absence of EtBr (Lane A). Further increases in the EtBr concentration (not shown) have little or no effect on either Form I or Form II. Adapted from electrophoresis data in Stettler et al, [9], Figure 12 , and from comparable data in $\mathrm{CsCl}$ velocity gradients, from Bauer \& Vinograd [27], Figure 8.

EtBr concentration, coincidentally co-migrating with Form I, it is quite impossible to imagine that it will do so at every EtBr concentration.

Our experimental protocol shall therefore be to recreate duplex circular DNA from its separated single strands, and to study its properties. Our control shall be native DNA, sham-treated with everything except the enzymes. We shall then subject both species to agarose gel electrophoresis at varying concentrations of EtBr, to obtain an "ethidium bromide fingerprint" for each.

What will the outcome of this experiment be?

According to "traditional" Watson-Crick theory, the EtBr should have the expected effect on the native DNA, as depicted in Figure 9, but either no effect at all, or, in any event, a markedly different effect on our experimentally re-constituted duplex DNA.

According to the non-helical point of view, however, the two species should have exactly the same ethidium bromide fingerprint, co-migrating at all EtBr 
concentrations, because the native and re-constituted DNA are the same thing.

There is thus no significant possibility of ambiguity in the outcome.

\subsubsection{Report on a Limited Experimental Result}

Having no lab of my own, I have labored in vain, for years, to persuade researchers to perform this experiment, with only a single success. About 10 years ago, a group of highly-motivated but inexperienced elementary-level biology lab students, at Lee University in Tennessee, endeavored to do the work [28]. They were able to produce a single electrophoretic study of a comparison of pBR322 native DNA, with pBR322 DNA reconstituted from the separated strands, prepared according to the protocol described in Figure 8 and the associated text. This was not the complete "ethidium bromide fingerprint" for this DNA, but

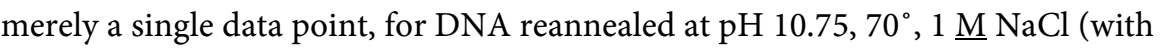
$0.1 \underline{\mathrm{M}}$ sodium phosphate, $3 \underline{\mathrm{mM}}$ EDTA), for 20 minutes.

The results are shown in Figure 10. The bands are faint, but show nevertheless that both species, that is, the native DNA and the reannealed DNA, essentially co-migrated in the gel. The small increment in the electrophoretic mobility of the control band was almost surely due to the fact that the students, seeking to "cut corners", had neglected to deproteinize the native DNA, although I had warned them that the native DNA, as isolated (or purchased), invariably contained small but significant amounts of histone-like bacterial proteins which slightly increased the tertiary winding, and hence the electrophoretic mobility. Please note that the DNA in the Experimental Lane of Figure 10 is not "Form V" because, as shown in Figure 3 and Figure 4, "Form V" migrates faster than Form I, not slower.

This is "student data", not publication-quality data, but I present it nevertheless, because it is the very best that the entirety of the world community of molecular biologists has been able to come up with in over 50 years, and in the hope that perhaps it will encourage others to try a little harder.

\subsubsection{Final Experiment: Alkali Denaturation, [NaCl] "Fingerprint"}

Let us now play "the devil's advocate". Suppose that the experiment goes entirely as we predict, with native and re-constituted DNA giving the exact same ethidium bromide "fingerprint". Would that end the matter?

Probably not. It is anticipated that many hard-line "helicists" would not be persuaded even by this, but would instead hypothesize, albeit for reasons which would defy explanation, that the re-constituted DNA might, for some unfathomable reason, co-migrate with native DNA at all concentrations of ethidium bromide. What else could we offer such skeptics?

The answer lies in the alkali denaturation experiment. At $\mathrm{pH} \mathrm{13,} \mathrm{as} \mathrm{we} \mathrm{saw} \mathrm{in}$ Figure 6, the compactness of native circular duplex DNA increases nearly threefold, due to its conversion to Form IV. If the density of our experimentally-reconstituted circular DNA also increases threefold at high $\mathrm{pH}$, then a non-helical structure for DNA is established with virtual certainty (since "traditional" Watson-Crick theory predicts only one possible outcome for alkali de- 


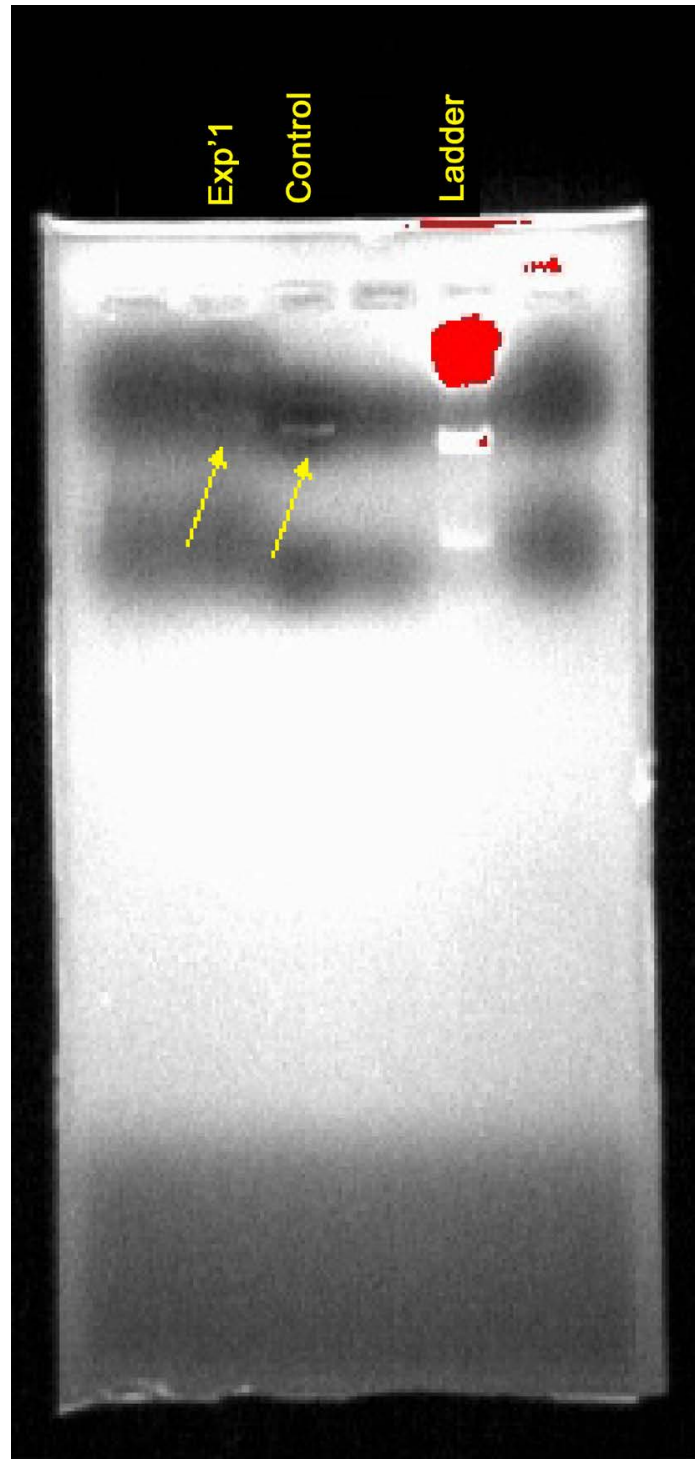

Figure 10. A group of elementary biology lab students at Lee University, Tennessee, decided to undertake the ethidium bromide "fingerprint" project described in the text [28]. In the time allotted, they managed to get only a single data point, creating a reconstituted duplex from the separated strands of pBR322 (separated according to the protocol illustrated in Figure 8), by reannealing the separated strands at $\mathrm{pH} 10.75,1 \underline{\mathrm{M} \mathrm{NaCl}}, 70^{\circ}$ (reannealing parameters taken from Strider [4] and Strider \& Warner [6]). The experimental band of intact DNA, although faint, is nevertheless clearly visible. A Form II band is also seen. The small discrepancy in banding position between the experimental and control DNA is explained in the text. The red color in the ladder is the result of either too much loading dye, DNA or both.

naturation of non-topologically-linked DNA: strand separation).

Repeating the entire Figure 6 Rush-Warner $\mathrm{pH}$ vs $s$ titration, however, would require an expensive and difficult series of ultracentrifugations. There's another, easier way to establish the identities and properties of the experimentallyreconstituted and native DNA, based upon a consideration of the effect of salt concentration on the compactness of alkali-denatured Form IV. The data in Figure 6 only shows the behavior of the DNA in a narrow range of salt concen- 
tration $(0.2-0.4 \underline{\mathrm{M}})$. We need to consider also the behavior of the Form IV DNA at other salt concentrations. In our final experiment, we shall do that.

\subsubsection{S vs. [NaCl] "Fingerprint"}

The Pouwels et al [24] data in Figure 7 show that the $S$ value of denatured circular DNA, i.e., Form IV, depends strongly upon salt concentration. Creating Form IV, from either native DNA or experimentally-reconstituted DNA (assuming, of course, that the latter can be done), would be easy, requiring merely the addition of $\mathrm{NaOH}$ to $\mathrm{pH}$ 13. The Figure 7 type of dependence upon salt concentration could then be readily ascertained by a series of electrophoresis runs.

This would enable us to obtain yet another "fingerprint" for the DNA, by performing electrophoresis under a series of different salt concentrations. The salt concentrations I would suggest are $0.03 \underline{\mathrm{M}}, 0.1 \underline{\mathrm{M}}, 0.3 \underline{\mathrm{M}}$, and $1.0 \underline{\mathrm{M} \mathrm{NaCl}}$, indicated by the blue text at the bottom of the logarithmic graph shown in Figure 7. If the experimental and control DNA both show the exact same linearlyincreasing rate of electrophoretic migration under those four conditions of salt concentration, then a non-helical structure for $\phi x 174$ DNA has thereby been absolutely established, since no two different substances can possibly have the same ethidium bromide "fingerprint" and salt "fingerprint"-unless some demon from a parallel universe is playing a trick on all humankind.

\section{Discussion}

Uneasiness about the double-helical structure goes back to the very beginning of modern DNA science, when, in 1954, Max Delbrück, James Watson's own mentor, pointed out the serious difficulties which arise when trying to account for the replication of a twisted duplex chromosome [29]. Starting in 1969 [20], and continuing up to the present day ([1] [7] [18] [30]-[37]), non-helical alternatives to the currently-accepted twisted structure have been published. In all this time, the existence of a net non-helical, paranemic structure for DNA has never been disproven. Quite to the contrary, a paranemic structure is supported by a substantial body of data, both theoretical [7] [8] [11] [12] [14] [20] [30]-[35] [37] and experimental [1] [25] [28] [36]. The molecular biological establishment has simply managed to cavalierly ignore this data for over 60 years.

The one exception was the year 1976, when Francis Crick suggested that topologically-non-helical DNA, i.e., "side-by-side" DNA, be made in the laboratory, specifically for the purpose of debunking the non-helical model as a plausible model for DNA in real life. Charles Weissmann "stepped up to the plate", and provided the suggested study (Stettler et al, 1979) [9]. That study, analyzed in some detail in the present manuscript, purported to have proved that side-byside DNA had an abnormal electrophoretic mobility, and that therefore the Watson-Crick model, for circular DNA, was proven. Unfortunately, as I have hopefully shown, the Weissmann study was fatally-flawed.

R.W. Chambers, at the same time, accidentally discovered that the separated strands of $\phi \times 174 \mathrm{RF}$, when merely incubated in the refrigerator, spontaneously 
reannealed back to the parental duplex, with its physical properties restored [25] [26]. Since that suggests that $\phi \times 174$ RF chromosomal DNA has no net helical twist that was therefore a finding of potentially surpassing importance. But Chambers never published it.

The molecular biological establishment, for reasons which baffle me, has been totally content to accept the flawed Weissmann study as the entirely of the necessary and sufficient proof to forever establish the net helicity of DNA, in all settings in which DNA is found. To the best of my knowledge, there has not, to date, been so much as a single additional attempt to either confirm or extend the conclusions of Stettler et al.

The above statement is certain to evoke incredulity on the part of the reader. Aren't there countless thousands of studies on DNA structure? Without a doubt, the body of literature on DNA structure is vast in size, and immense in scope. But the primary tools of DNA structural study, namely $x$-ray crystallography and NMR spectroscopy, cannot be applied to either small plasmid DNA, or to bacterial or eukaryotic DNA in the natural setting.

Moreover, an examination of the vast literature on DNA structural studies reveals the startling fact that, almost without exception, the DNA employed in such studies has undergone one or more of the following perturbations, any one of which would exclude it as a reliable model for DNA structure in fully-intact chromatin:

1) First of all, the DNA has been removed from the nucleus, and "purified", which means that it has been separated from proteins-histones and protamines-which are essentially long chains of powerfully-positively-charged lysine and arginine residues, whereas DNA is essentially a long chain of negatively-charged phosphate groups. If we were to accept the majority opinion, we would thereby be compelled to believe that the removal of histones and protamines will have no effect on DNA structure. How can such a thing be? The idea that the disruption of such massive charge-charge interaction will have no effect on structure is preposterous on the face of it, and totally contrary to all scientific logic. (It should be specifically noted, in this regard, that the currently-accepted nucleosome DNA-histone structure, which has multiple orders of twisting, is utterly synthetic, created from individually-isolated DNA and histone subunits, all of which are reconstituted in the laboratory, into what may prove to be a grand artifact).

2) Secondly, in the process of "purification" of chromosomes, they are broken into hundreds of thousands, or millions of pieces. There is simply no way to avoid this. We see, in articles about chromatin extraction, terms such as "gentle lysis", which is something of a joke. Even a small chromosome, such as that of E. coli, cannot be isolated intact. The idea that the procedures that are employed to isolate either bacterial DNA, or the thousand-fold-larger eukaryotic DNA, which can only result in a vast and random conglomeration of broken fragments, should be regarded as "gentle", is almost insulting to the intelligence. In actual fact, any aspect of chromosomal DNA structure which is dependent upon 
chromosomal integrity is irrevocably lost, as soon as the nucleus is lysed. What sort of false logic compels us to believe that DNA in the intact, unmolested chromosome must have the same structure it has in the extensively-fragmented laboratory artifact?

3) DNA intended for structural studies, in an astonishingly large percentage of cases, is first treated with various enzymes that nick and/or seal the sugarphosphate backbone (nucleases, topoisomerases, ligases, etc.), thus destroying any aspect of chromosomal integrity dependent upon the maintenance of the native linking number $\left(\mathrm{L}_{\mathrm{K}}\right)$. The authors of these studies all seem to think that this doesn't matter. How can this possibly not matter, unless it is presumed, in advance, that DNA in native chromatin has exactly the same linking number as DNA in "purified" form (i.e., stripped of protein and extensively fragmented)? Does this not "beg the question"?

4) DNA intended for $x$-ray crystallography must be dehydrated. The allegation that dehydrated DNA in the lab must have the same structure as DNA in the $\sim 100 \%$ humidity conditions of the cell nucleus, is as ridiculous as alleging that a dried peach in the canned food section of the grocery store must have the same structure as a live peach hanging from the tree that produced it.

Since the primary tools used in DNA structural research, i.e., x-ray crystallography and NMR spectroscopy, plainly and simply cannot be used on intact chromatin, the widely-held alleged equivalence of laboratory DNA structure and intracellular DNA structure is therefore merely a presumption, unsupported by any compelling physical evidence. The pressure we are all under, to blindly accept this equivalence nevertheless, is contrary to the established principles of scientific inquiry that have prevailed in the world since the Renaissance.

There is thus a huge gap in our knowledge of native DNA structure, because that knowledge may prove to be based upon the study of laboratory artifacts that differ substantially from the native form. The experiments suggested in the present manuscript, which are proposed to 1) non-destructively separate the strands of a plasmid, and 2) reconstitute them to the native duplex form, will hopefully go a long way toward filling that gap in our knowledge.

I have labored for 44 years in this rather thankless area of human scientific endeavor. I am, by trade, a physician in private practice, and I have no access to the sort of laboratory necessary to do high-quality DNA structural research. Most of my work has therefore been directed at the creation of theoretical models, but that has been interspersed with sporadic efforts to recruit the cooperation of other scientists who are better-equipped than I, to do the physical research. To date, none have cooperated. The number of scientists with whom I have communicated, since 1972, whose names I maintain on a list, is over 500. Each one is so certain that DNA is helical, that they will not even look at the data, much less perform the necessary experiments.

I am 67 years old, and I have far less time before me than behind me. I therefore publish these strand-separating and strand-reannealing protocols in the hope that the readers of OALib will take up this cause. It is a worthwhile cause. 
As Crick himself said, "DNA is such an important molecule that it is almost impossible to learn too much about it" [38].

\section{References}

[1] Wu, R. and Wu, T.T. (1996) A Novel Intact Circular dsDNA Supercoil. Bulletin of Mathematical Biology, 58, 1171-1185. https://doi.org/10.1007/BF02458388

[2] Weil, R. and Vinograd, J (1963) The Cyclic Helix and Cyclic Coil Forms of Polyoma viral DNA. Proceedings of the National Academy of Sciences, 50, 730-738. http://www.ncbi.nlm.nih.gov/pmc/articles/PMC221253/pdf/pnas00238-0150.pdf

[3] Weil, R. (1963) The Denaturation and the Renaturation of the DNA of Polyoma Virus. Proceedings of the National Academy of Sciences, 49, 480-487. https://www.ncbi.nlm.nih.gov/pmc/articles/PMC299883/ https://doi.org/10.1073/pnas.49.4.480

[4] Strider, W. (1971) Denatured Replicative Form and Complex DNA of øX174: Isolation, Renaturation, and Sedimentation Properties. PhD Dissertation, Department of Biochemistry, New York University School of Medicine, New York.

[5] Strider, W. and Warner, R.C. (1971) Denatured Replicative Form and Complex DNA of $ø$ X174: Isolation and Renaturation. Federation Proceedings, 30, 1053.

[6] Strider, W., Camien, M.N. and Warner, R.C. (1981) Renaturation of Denatured, Covalently Closed Circular DNA. Journal of Biological Chemistry, 256, 7820-7829. http://www.jbc.org/content/256/15/7820.full.pdf

[7] Biegeleisen, K. (2016) The Probable Structure of "Form IV" (Alkali-Denatured Circular DNA). Open Access Library Journal, 3, Article ID: e2386.

https://doi.org/10.4236/oalib.1103114

[8] Biegeleisen, K. (2016) Form IV: The Final Puzzle Piece. https://notahelix.net

[9] Stettler, U.H., Weber, H., Koller, T. and Weissmann, C. (1979) Preparation and Characterization of form V DNA, the Duplex DNA Resulting from Association of Complementary, Circular Single-Stranded DNA. Journal of Molecular Biology, 131, 21-40. https://doi.org/10.1016/0022-2836(79)90299-7

[10] Rush, M.G. and Warner, R.C. (1970) Alkali Denaturation of Covalently Closed Circular Duplex Deoxyribonucleic Acid. Journal of Biological Chemistry, 245, 27042708. http://www.jbc.org/content/245/10/2704.full.pdf+html

[11] Biegeleisen, K. (2016) The Double Non-Helix Part 1: The Science and History of Topologically Non-Linked DNA. https://notahelix.net

[12] Biegeleisen, K. (2016) The Double Non-Helix Part 2: The Probable Structure of the Protamine-DNA Complex. https://notahelix.net

[13] Biegeleisen, K. (2016) Histone Structure. Part 1: Current Concepts. https://notahelix.net

[14] Biegeleisen, K. (2016) Histone Structure. Part 2: A Model Which Places the DNA in the N-Terminal Region of the Octamer. https://notahelix.net

[15] Biegeleisen, K. (2016) Histone Structure. Part 3: Possible New Structure for Chromosomes. https://notahelix.net

[16] Biegeleisen, K. (2016) Form IV: The Final Puzzle Piece. Slides 145-160. https://notahelix.net

[17] Biegeleisen, K. (2016) The Double Non-Helix Part 1: The Science and History of Topologically Non-Linked DNA. Slides 302-345. https://notahelix.net

[18] Rodley, G.A., Scobie, R.S., Bates, R.H.T. and Lewitt, R.M. (1976) A Possible Con- 
formation for Double-Stranded Polynucleotides. Proceedings of the National Academy of Sciences USA, 73, 2959-2963.

http://www.ncbi.nlm.nih.gov/pmc/articles/PMC430891/pdf/pnas00039-0021.pdf https://doi.org/10.1073/pnas.73.9.2959

[19] Biegeleisen, K. (2016) Form IV: The Final Puzzle Piece. Slides 147-148.

https://notahelix.net

[20] Wu, T.T. (1969) Secondary Structures of DNA. Proceedings of the National Academy of Sciences USA, 63, 400-405.

http://www.pnas.org/content/63/2/400.full.pdf+html https://doi.org/10.1073/pnas.63.2.400

[21] Watson, J.D. and Crick, F.H.C. (1953) A Structure for Deoxyribose Nucleic Acid. Nature, 171, 737-738. http://www.nature.com/nature/dna50/watsoncrick.pdf

[22] Yakovchuk, P., Protozanova, E. and Frank-Kamenetskii, M. (2006) Base-Stacking and Base-Pairing Contributions into Thermal Stability of the DNA Double Helix. Nucleic Acids Research, 34, 564-574. https://doi.org/10.1093/nar/gkj454

[23] Biegeleisen, K. (2016) The Double Non-Helix Part 1: The Science and History of Topologically Non-Linked DNA. Slides 324-328. https://notahelix.net

[24] Pouwels, P.H., Knijnenburg, C.M., Van Rotterdam, J., Cohen, J.A. and Jansz, H.S. (1968) Structure of the Replicative form of Bacteriophage $\phi X 174$. VI. Studies on Alkali-Denatured Double-Stranded $\phi X$ DNA. Journal of Molecular Biology, 32, 169-182. https://doi.org/10.1016/0022-2836(68)90002-8

[25] Chambers, R.W. (1978) Personal Communication. Prof. Chambers, Now Retired, Has Provided Written Consent for These Unpublished Results to Be Publicly Quoted.

[26] Biegeleisen, K. (2016) The Double Non-Helix Part 1: The Science and History of Topologically Non-Linked DNA. Slides 346-358. https://notahelix.net

[27] Bauer, W. and Vinograd, J. (1968) The Interaction of Closed Circular DNA with Intercalative Dyes. I. The Superhelix Density of SV40 DNA in the Presence and Absence of Dye. Journal of Molecular Biology, 33, 141-171. https://doi.org/10.1016/0022-2836(68)90286-6

[28] West, L., Henley, A., Hathaway, S., Ownby, C., Adhikari, J. and Abana, C. (2007) Unpublished Study from Lee University Biology Laboratory, Cleveland.

[29] Delbrück, M. (1954) On the Replication of Desoxyribonucleic Acid (DNA). Proceedings of the National Academy of Sciences, 40, 783-788.

http://www.pnas.org/content/40/9/783.full.pdf https://doi.org/10.1073/pnas.40.9.783

[30] Sasisekharan, V., Pattabiraman, N. and Gupta, G. (1976) Double Stranded Polynucleotides: Two Typical Alternative Conformations for Nucleic Acids. Current Science, 45, 779-783.

[31] Cyriax, B. and Gäth, R. (1978) The Conformation of Double-Stranded DNA. Naturwissenschaften, 65, 106-108. https://doi.org/10.1007/BF00440551

[32] Pohl, W.F. and Roberts, G.W. (1978) Topological Considerations in the Theory of Replication of DNA. Journal of Mathematical Biology, 6, 383-402. https://doi.org/10.1007/BF02463003

[33] Biegeleisen, K. (2002) Topologically Non-Linked Circular Duplex DNA. Bulletin of Mathematical Biology, 64, 589-609. https://doi.org/10.1006/bulm.2002.0288

[34] Delmonte, C. and Mann, L.R.B. (2003) Variety in DNA Secondary Structure. Current Science, 85, 1564-1570. http://www.iisc.ernet.in/currsci/dec102003/1564.pdf 
[35] Biegeleisen, K. (2006) The Probable Structure of the Protamine-DNA Complex. Journal of Theoretical Biology, 241, 533-540. https://doi.org/10.1016/j.jtbi.2005.12.015

[36] Xu, Y.C. (2009) Finding of a Zero Linking Number Topoisomer. Biochimica et Biophysica Acta, 1790, 126-133. https://doi.org/10.1016/j.bbagen.2008.10.012

[37] Biegeleisen, K. (2016) A New Histone Structure Which Binds DNA at Its Eight Subunit N-Termini. Open Access Library Journal, 3, Article ID: e2386. https://doi.org/10.4236/oalib.1102386

[38] Crick, F.H.C., Wang, J.C. and Bauer, W.R. (1979) Is DNA Really a Double Helix? Journal of Molecular Biology, 129, 449-461.

http://profiles.nlm.nih.gov/ps/access/SCBCDD.pdf

https://doi.org/10.1016/0022-2836(79)90506-0

Submit or recommend next manuscript to OALib Journal and we will provide best service for you:

- Publication frequency: Monthly

- 9 subject areas of science, technology and medicine

- Fair and rigorous peer-review system

- Fast publication process

- Article promotion in various social networking sites (LinkedIn, Facebook, Twitter, etc.)

- Maximum dissemination of your research work

Submit Your Paper Online: Click Here to Submit

Or Contact service@oalib.com 